\title{
Antimicrobial agents of 4-methoxysalicylaldehyde isolated from Periploca sepium oil against foodborne bacteria: structure-activity relationship
}

\author{
Eun-Young Jeong ${ }^{1} \cdot$ Myung-Ji Lee $^{1} \cdot$ Min-Seung Kang ${ }^{1} \cdot$ \\ Hoi-Seon Lee ${ }^{1}$
}

Received: 17 April 2018/Accepted: 3 May 2018/Published online: 15 May 2018

(C) The Korean Society for Applied Biological Chemistry 2018

\begin{abstract}
This study was designed to evaluate the antimicrobial activities of 4-methoxysalicylaldehyde isolated from Periploca sepium and its derivatives against six foodborne bacteria (Listeria monocytogenes, Salmonella typhimurium, Shigella flexneri, S. sonnei, Staphylococcus intermedius and $S$. aureus). Essential oil extracted from $P$. sepium roots exhibits strong antimicrobial activity against foodborne bacteria. The antimicrobial compound of $P$. sepium isolated by chromatographic techniques was identified as 4-methoxysalicylaldehyde. To compare the antimicrobial activities of 4-methoxysalicylaldehyde and its derivatives (4-hydroxysalicylaldehyde, salicylaldehyde, 3-methoxysalicylaldehyde, 5-methoxysalicylaldehyde, 3-methylsalicylaldehyde, and 5-methylsalicylaldehyde), the MIC test was performed. These activities were exhibited by 4-methoxysalicylaldehyde (MIC 30.1-67.3 $\mu \mathrm{g} / \mathrm{mL}$ ) followed by 4-hydroxysalicylaldehyde (MIC 41.1-61.5 $\mu \mathrm{g}$ / $\mathrm{mL}$ ) and 4-methoxysalicylaldehyde (MIC 41.3-92.1 $\mu \mathrm{g} /$ $\mathrm{mL}$ ) against all tested microorganisms. The results indicate that 4-methoxysalicylaldehyde and its derivatives represent natural antimicrobial alternatives.
\end{abstract}

Keywords Antimicrobial agent · Foodborne bacteria - 4Methoxysalicylaldehyde · Periploca scepium

Eun-Young Jeong and Myung-Ji Lee as first author contributed equally to this study.

Hoi-Seon Lee

hoiseon@jbnu.ac.kr

1 Department of Bioenvironmental Chemistry, Chonbuk National University, Jeonju 54896, Republic of Korea

\section{Introduction}

Microbial contamination and food spoilage are one of the causes of foodborne disease, which appears to increase the focus of attention on food safety [1-3]. Infectious diseases including foodborne disease are one of the main causes of global health problems in developing countries [1, 2, 4]. Synthetic preservatives are used for food processing in order to prolong the expiration date and safety of foods. However, the side effects associated with synthetic preservatives and their impact on human health question the stability of synthetic preservatives $[2,5]$. In recent years, the role of natural products and growing apprehension about the safety of synthetic antibiotics has stimulated various studies of plant materials [2, 4].

Plant-derived products have been used to manufacture acaricides, insecticides, traditional medicines, and for protection against foodborne pathogens [1, 2, 6, 7]. Plant essential oils and their constituents are potential antimicrobial agents and food preservatives [2, 5, 8, 9]. Such oils represent attractive antimicrobial agents as they reduce the risk of pathogenic bacterial resistance and generally display low toxicities in mammals, unlike synthetic antibiotics or food preservatives $[2,4,5,10]$. Periploca sepium Bunge (Asclepiadaceae), widespread throughout northeastern and southwestern China, has been traditionally used as a Chinese herbal medicine. P. sepium roots are also used for treatment of rheumatoid arthritis, cardiac palpitation, shortness of breath and wounds, which is attributed to its oligosaccharides, pregnane glycosides, flavonoids and triterpenoids [11-13]. This study was undertaken with the main objective of identifying active component in $P$. sepium roots, and to investigate the antimicrobial activity of its constituents against six foodborne pathogens. 


\section{Materials and methods}

\section{Chemicals}

4-Hydroxysalicylaldehyde, 3-methoxysalicylaldehyde, 5-methoxysalicylaldehyde, 3-methylsalicylaldehyde, 5-methylsalicylaldehyde and salicylaldehyde were obtained from Sigma-Aldrich Chemical Co. (St. Louis, MO, USA).

\section{Isolation and identification}

Roots of $P$. sepium were purchased from Jeonju market (Korea). Extracted oil of $P$. sepium roots was obtained through steam distillation for $4 \mathrm{~h}$. The oil yield was $0.24 \%$ and stored at $4{ }^{\circ} \mathrm{C}$ in a refrigerator. Essential oil $(4 \mathrm{~g})$ was loaded to silica gel chromatography (70-230 mesh; diameter, $8 \times 90 \mathrm{~cm}$; $600 \mathrm{~g}$; Merck, Rahway, NJ, USA) for purification. Essential oil was eluted with ethyl acetate:hexane $(0: 10-10: 0, \mathrm{v} / \mathrm{v})$ to obtain five fractions (PS1 to PS5). Five fractions were bioassayed against six foodborne bacteria. The PS3 fraction exhibited strong antimicrobial activity. Active PS3 was re-chromatographed and eluted by multi-step solvent gradients as follows: ethyl acetate:hexane (2:8-5:5, v/v). A Jaigel GS series column (GS-310 $500 \mathrm{~mm}$ plus GS-310 $300 \mathrm{~mm}$ ) was connected to a recycling prep HPLC (Japan Analytical Industry Co. Ltd., Tokyo, Japan) and equilibrated with acetone (100\%). Active PS32 (3.8 g) was injected into HPLC and eluted at $1 \mathrm{~mL} / \mathrm{min}$ (flow rate) and UV was determined out at $294 \mathrm{~nm}$. PS321 and PS322 were obtained and bioassayed at $5.0 \mathrm{mg} /$ disc. The PS321 fraction showed the strongest activity against six foodborne bacteria at $5.0 \mathrm{mg} / \mathrm{disc}$. Finally, PS321 (3.5 g, yield 68.9\%), was isolated by prep HPLC.

The PS321 structure was demonstrated by spectroscopic techniques. ${ }^{1} \mathrm{H}$ - and ${ }^{13} \mathrm{C}-\mathrm{NMR}$ spectra were studied using a JNM-ECA600 spectrometer (JEOL Ltd., Tokyo, Japan) instrument with $\mathrm{CHCl}_{3}$ as the solvent and $\mathrm{C}_{4} \mathrm{H}_{12} \mathrm{Si}$ as the internal standard. The UV-visible light absorption spectrum was also obtained with $\mathrm{CHCl}_{3}$ using a UV spectrometer (DR/4000 spectrophotometer, HACH, Seoul, Korea). In addition, EI-MS was determined using a JEOL JMS-DX 30 mass spectrometer.

\section{Bacterial culture}

Six foodborne bacteria were tested in this study, including three Gram-positive bacteria: Staphylococcus aureus ATCC 25923, Listeria monocytogenes ATCC 15313, and Staphylococcus intermedius ATCC 29663; three Gramnegative bacteria: Shigella sonnei ATCC 25931,
Salmonella typhimurium IFO 14193, and Shigella flexneri ATCC 29903. The pure bacterial strains were obtained from the Korean Culture Center of Microorganisms (Seoul, Korea). All bacteria were grown aerobically at $37^{\circ} \mathrm{C}$ in nutrient broth (NB; Difco, USA) while $S$. aureus were grown in Tryptic Soy broth (TSB; Difco, USA).

\section{Disc diffusion}

Antimicrobial activity of $P$. sepium oil, 4-hydroxysalicylaldehyde and its derivatives were determined via disc diffusion method, as suggested by Kim et al. [14], against six foodborne bacteria. First, the bacterial suspensions were cultured in NB and then diluted to a turbidity adjusted to that of $0.5 \mathrm{McF}$ arland (containing approximately $1.0 \times 10^{7}$ $\mathrm{CFU} / \mathrm{mL}$ ). The Muller Hinton agar (MHA; Difco, USA) plate was inoculated with bacterial suspensions $(100 \mu \mathrm{L})$ containing $10^{7} \mathrm{CFU} / \mathrm{mL}$. The sterilized paper discs were soaked with $40 \mu \mathrm{L}$ of each dilution (P. sepium oil, 4-hydroxysalicylaldehyde and its derivatives) (20 to $0.125 \mathrm{mg} /$ disc) and placed on each MHA plate [15]. Methanol as negative control was also injected into the discs. The plates were left in an incubator at $37{ }^{\circ} \mathrm{C}$ for $24 \mathrm{~h}$. Analytical experiments were conducted in triplicate.

\section{Minimum inhibitory concentrations}

Antimicrobial activities of 4-hydroxysalicylaldehyde and its derivatives were investigated via the minimum inhibitory concentration (MIC) using the broth dilution method. The MIC test was conducted by dissolving P. sepium oil, 4-hydroxysalicylaldehyde and its derivative $(10 \mathrm{mg})$ and serially diluted two-fold in methanol $(10 \mathrm{~mL})$ in order to obtain $100-1 \mu \mathrm{g} / \mathrm{mL}$ concentrations; $100 \mu \mathrm{L}$ of Muller Hinton broth (MHB) containing tested samples $(50 \mu \mathrm{L})$ was dispensed into a 96-well microtiter plates using a micro-pipette followed by the addition of $50 \mu \mathrm{L}$ bacterial suspension $\left(10^{7} \mathrm{CFU} / \mathrm{mL}\right)$. All plates without tested samples were used as a control. After all plates were incubated at $37^{\circ} \mathrm{C}$ for $24 \mathrm{~h}$, the MIC values were determined based on turbidity at $600 \mathrm{~nm}$.

\section{Results and discussion}

Antimicrobial activity of the oil extracted from P. sepium roots was evaluated via the disc diffusion method (Table 1). Measurements of inhibition zone values of the extracted oil of $P$. sepium roots showed potent antimicrobial activities against $S$. aureus, $L$. monocytogenes, $S$. sonnei, and S. typhimurium. By contrast, the essential oil of $P$. serpium was less active against $S$. intermedius and $S$. flexneri. The negative control lacked antimicrobial activity 
Table 1 Antimicrobial activities of essential oil of $P$. sepium seeds against foodborne bacteria

\begin{tabular}{|c|c|c|c|c|c|c|c|}
\hline \multirow[t]{3}{*}{ Sample } & \multirow[t]{3}{*}{ Conc. (mg/disc) } & \multicolumn{6}{|l|}{ Bacterial species } \\
\hline & & \multicolumn{3}{|c|}{ Gram-positive bacteria } & \multicolumn{3}{|c|}{ Gram-negative bacteria } \\
\hline & & L. monocytogenes & S. aureus & S. intermedius & S. typhimurium & S. flexneri & S. sonnei \\
\hline \multirow[t]{4}{*}{ P. sepium oil } & 20 & $++++^{\mathrm{a}}$ & ++++ & ++ & ++++ & ++ & +++ \\
\hline & 10 & +++ & +++ & + & +++ & + & ++ \\
\hline & 5 & ++ & +++ & - & +++ & - & ++ \\
\hline & 2 & ++ & + & - & ++ & - & + \\
\hline Negative control (only solvent) & 20 & - & - & - & - & - & - \\
\hline
\end{tabular}

Cultured on Mueller-Hinton agar at $37^{\circ} \mathrm{C}$ for $24 \mathrm{~h}$ in an incubator

${ }^{a}$ Diameter of inhibition zone $>30 \mathrm{~mm} ;++++$; $21-30 \mathrm{~mm},+++; 16-20 \mathrm{~mm},++; 10-15 \mathrm{~mm},+$; and $<10 \mathrm{~mm},-$

against the microorganisms tested. Wang et al. [16] reported that the $P$. sepium oil showed antimicrobial and antioxidant activities against a wide range of bacterial strains. In addition, $P$. sepium also exhibited insecticidal $[12,17]$ and acaricidal activities [18]. In addition, similar studies have been demonstrated for species such as Periploca laevigata [3].

The antimicrobial compound was isolated by bioassayguided separation and identified spectroscopically. Spectroscopic analysis verified PS321 as 4-methoxysalicylaldehyde (Tables 2, 3). Spectroscopic data for 4-methoxysalicylaldehyde (4-methoxy-2-hydroxybenzaldehyde $)\left(\mathrm{C}_{8} \mathrm{H}_{8} \mathrm{O}_{3}\right.$, molecular weight 151.0$)$ were as follows: EI-MS $(70 \mathrm{eV}) \mathrm{m} / \mathrm{z} \mathrm{M}^{+} 151,134,108,95,69,53$, $32 ;{ }^{1} \mathrm{H} \quad \mathrm{NMR}\left(\mathrm{CD}_{3} \mathrm{OD}, 600 \mathrm{MHz}\right) \delta 11.42(1 \mathrm{H}, \mathrm{t}$, $J=7.2 \mathrm{~Hz}), 7.30 \quad(1 \mathrm{H}, \quad \mathrm{t}, \quad J=10.1 \mathrm{~Hz}), 6.47 \quad(1 \mathrm{H}, \mathrm{t}$, $J=0.9 \mathrm{~Hz}), 6.38(1 \mathrm{H}, \mathrm{t}, J=8.1 \mathrm{~Hz}), 4.60(1 \mathrm{H}, \mathrm{s}), 3.80$ $(1 \mathrm{H}, \mathrm{m}, J=14.5 \mathrm{~Hz})$; and ${ }^{13} \mathrm{C} \mathrm{NMR}\left(\mathrm{CDCl}_{3}, 150 \mathrm{MHz}\right) \delta$ $194.5(\mathrm{CH}), 166.9(\mathrm{C}-\mathrm{O}), 164.9(\mathrm{C}-\mathrm{OH}), 135.3(\mathrm{CH})$, $115.2(\mathrm{C}), 108.5(\mathrm{CH}), 100.7(\mathrm{CH}), 55.7\left(\mathrm{CH}_{3}\right)$. Antimicrobial effects of the oil derived from $P$. sepium roots

Table $2{ }^{1} \mathrm{H}$ NMR, ${ }^{13} \mathrm{C}$ NMR, and DEPT spectral data ${ }^{\mathrm{a}}$ of PS321

\begin{tabular}{llll}
\hline Carbon & Partial structure & $\delta_{\mathrm{C}}(\mathrm{ppm})$ & $\delta_{\mathrm{H}}(\mathrm{ppm})$ \\
\hline 1 & $\mathrm{CH}$ & 194.5 & $11.42\left(1 \mathrm{H}, \mathrm{t}^{\mathrm{b}}, J=7.2 \mathrm{~Hz}\right)$ \\
2 & $\mathrm{C}-\mathrm{O}$ & 166.9 & \\
3 & $\mathrm{C}-\mathrm{OH}$ & 164.9 & $4.60(1 \mathrm{H}, \mathrm{s})$ \\
4 & $\mathrm{CH}$ & 135.3 & $7.30(1 \mathrm{H}, \mathrm{t}, J=10.1 \mathrm{~Hz})$ \\
5 & $\mathrm{C}$ & 115.2 & \\
6 & $\mathrm{CH}$ & 108.5 & $6.47(1 \mathrm{H}, \mathrm{t}, J=0.9 \mathrm{~Hz})$ \\
7 & $\mathrm{CH}$ & 100.7 & $6.38(1 \mathrm{H}, \mathrm{t}, J=8.1 \mathrm{~Hz})$ \\
8 & $\mathrm{CH}_{3}$ & 55.7 & $3.80(1 \mathrm{H}, \mathrm{m}, J=14.5 \mathrm{~Hz})$ \\
\hline
\end{tabular}

${ }^{\mathrm{a} 1} \mathrm{H} \mathrm{NMR}(600 \mathrm{MHz}),{ }^{13} \mathrm{C}$ NMR and DEPT (150 MHz), TMS, $\delta$ ppm, $J$ in $\mathrm{Hz}$

$\mathrm{b}_{\mathrm{s}}$ : singlet, $\mathrm{d}$ : doublet, $\mathrm{t}$ : triplet, $\mathrm{m}$ : multiplet
Table 3 Structures of 4-methoxysalicylaldehyde analogues

\begin{tabular}{|c|c|c|c|c|}
\hline $\mathrm{R}_{3}$ & $\mathrm{OH}$ & & & \\
\hline Chemicals & $\mathrm{R}_{1}$ & $\mathrm{R}_{2}$ & $\mathrm{R}_{3}$ & $\mathrm{R}_{4}$ \\
\hline 4-Methoxysalicylaldehyde & $\mathrm{H}$ & $\mathrm{CH}_{3} \mathrm{O}$ & $\mathrm{H}$ & $\mathrm{H}$ \\
\hline 4-Hydroxysalicylaldehyde & $\mathrm{H}$ & $\mathrm{OH}$ & $\mathrm{H}$ & $\mathrm{H}$ \\
\hline Salicylaldehyde & $\mathrm{H}$ & $\mathrm{H}$ & $\mathrm{H}$ & $\mathrm{H}$ \\
\hline 3-Methoxysalicylaldehyde & $\mathrm{CH}_{3} \mathrm{O}$ & $\mathrm{H}$ & $\mathrm{H}$ & $\mathrm{H}$ \\
\hline 5-Methxoysalicylaldehyde & $\mathrm{H}$ & $\mathrm{H}$ & $\mathrm{CH}_{3} \mathrm{O}$ & $\mathrm{H}$ \\
\hline 3-Methylsalicylaldehyde & $\mathrm{CH}_{3}$ & $\mathrm{H}$ & $\mathrm{H}$ & $\mathrm{H}$ \\
\hline 5-Methylsalicylaldehyde & $\mathrm{H}$ & $\mathrm{H}$ & $\mathrm{CH}_{3}$ & $\mathrm{H}$ \\
\hline
\end{tabular}

depend on the presence of high content of 4-methoxysalicylaldehyde [16]. Analytical data of 4-methoxysalicylaldehyde were consistent with reported studies [12, 16, 19]. Decalepis arayalpathra, Decalepis hamiltonii, and Hemidesmus indicus roots contain 4-methoxysalicylaldehyde [20, 21], which has been widely utilized in soft drinks and bakery products as a flavoring agent and for extending the shelf-life of food [16, 22].

To investigate the structure-activity relationships of 4-methoxysalicylaldehyde and its derivatives, 4-hydroxysalicylaldehyde, salicylaldehyde, 3-methoxysalicylaldehyde, 5-methoxysalicylaldehyde, 3-methylsalicylaldehyde, 
and 5-methylsalicylaldehyde were selected (Table 3). Antimicrobial activities of 4-methoxysalicylaldehyde and its analogues were examined against six foodborne bacteria via disc diffusion (Table 4). Among compounds with methoxy group in the $\mathrm{C}-4$ position of the salicylaldehyde, 4-methoxysalicylaldehyde exhibited strong-to-moderate antimicrobial activities against six foodborne bacteria at 2.0-1.0 mg/disc. However, 4-mexthoxysalicylaldehyde exhibited weak or no antimicrobial activity against the microorganisms tested at $0.5 \mathrm{mg} /$ disc. Similarly, among compounds with methoxy group in the C-5 position of the salicylaldehyde, 5-methoxysalicylaldehyde showed strongto-weak antimicrobial activities against all the tested bacteria at $2.0 \mathrm{mg} / \mathrm{disc}$. In contrast, 3-methoxysalicylaldehyde, which carries a methoxy group in the $\mathrm{C}-3$ position of the salicylaldehyde, did not show antimicrobial activity against six foodborne bacteria. In this regard, the altered position of methoxy group on salicylaldehyde appeared to affect the antimicrobial activities against six foodborne bacteria. At a dose of 2.0-1.0 mg/disc, 4-hydroxysalicylaldehyde, which has a salicylaldehyde conjugated with the hydroxy group in the C-4 position, also demonstrated enormous antimicrobial activity against six foodborne bacteria. Especially, $S$. aureus was the most susceptible to 4-hydroxysalicylaldehyde at $0.125 \mathrm{mg} /$ disc. The difference between 4-hydroxysalicylaldehyde and others relates to a single additional hydroxyl group in the position of salicylaldehyde. Studies demonstrated that the addition of an extra hydroxyl group in the benzaldehyde derivatives resulted in enhanced antimicrobial activity [2, 23]. The observations were similar to a previous study conducted by Stojković et al. [24] who reported that caffeic acid containing two hydroxyl groups exhibited a higher antimicrobial activity than $p$ coumaric acid, containing a single hydroxyl group. Salicylaldehyde displayed limited antimicrobial activity against S. typhimurium, S. aureus, L. monocytogenes, and $S$. flexneri except for $S$. intermedius and S. sonnei. However, 3-methylsalicylaldehyde and 5-methylsalicylaldehyde, which contain a methyl group in the C-3 and C-5 positions of the salicylaldehyde, showed no antimicrobial activities against six foodborne bacteria at exposure levels of $2.0 \mathrm{mg} /$ disc.

The MIC values of 4-methoxysalicylaldehyde and its derivatives required for inhibitory activity against six foodborne bacteria are listed in Table 5. In addition, not only 4-methoxysalicylaldehyde (MIC 30.1-67.3 $\mu \mathrm{g} / \mathrm{mL}$ ) but also 4-hydroxysalicylaldehyde (MIC 41.1-61.5 $\mu \mathrm{g}$ / $\mathrm{mL}$ ) inhibited the growth of six foodborne bacteria. 5-Methoxysalicylaldehyde showed a moderate inhibitory activity (MIC 41.3-92.1 $\mu \mathrm{g} / \mathrm{mL}$ ), whereas salicylaldehyde exhibited inhibitory activity (MIC 62.8-81.5 $\mu \mathrm{g} / \mathrm{mL}$ ) against all the tested microorganisms except for

Table 4 Antimicrobial activities of 4-methoxysalicylaldehyde and its derivatives against foodborne bacteria

\begin{tabular}{|c|c|c|c|c|c|c|c|}
\hline \multirow[t]{3}{*}{ Compound } & \multirow[t]{3}{*}{ Conc. (mg/disc) } & \multicolumn{6}{|l|}{ Bacterial species } \\
\hline & & \multicolumn{3}{|c|}{ Gram-positive bacteria } & \multicolumn{3}{|c|}{ Gram-negative bacteria } \\
\hline & & L. monocytogenes & S. aureus & S. intermedius & S. typhimurium & S. flexneri & S. sonnei \\
\hline \multirow[t]{3}{*}{ 4-Methoxysalicylaldehyde } & 2.0 & $+++^{\mathrm{a}}$ & +++ & ++ & +++ & ++ & +++ \\
\hline & 1.0 & ++ & ++ & + & ++ & ++ & ++ \\
\hline & 0.5 & + & + & - & ++ & + & + \\
\hline \multirow[t]{5}{*}{ 4-Hydroxysalicylaldehyde } & 2.0 & ++ & +++ & +++ & +++ & + & +++ \\
\hline & 1.0 & + & ++ & ++ & ++ & + & ++ \\
\hline & 0.5 & - & ++ & + & ++ & - & ++ \\
\hline & 0.25 & - & + & - & + & - & + \\
\hline & 0.125 & - & + & - & - & - & - \\
\hline \multirow[t]{2}{*}{ Salicylaldehyde } & 2.0 & ++ & + & - & + & + & - \\
\hline & 1.0 & + & - & - & + & + & - \\
\hline 3-Methoxysalicylaldehyde & 2.0 & - & - & - & - & - & - \\
\hline \multirow[t]{3}{*}{ 5-Methxoysalicylaldehyde } & 2.0 & + & ++ & + & +++ & ++ & +++ \\
\hline & 1.0 & - & + & + & ++ & + & ++ \\
\hline & 0.5 & - & - & - & + & - & + \\
\hline 3-Methylsalicylaldehyde & 2.0 & - & - & - & - & - & - \\
\hline 5-Methylsalicylaldehyde & 2.0 & - & - & - & - & - & - \\
\hline
\end{tabular}

Cultured on Mueller-Hinton agar at $37{ }^{\circ} \mathrm{C}$ for $24 \mathrm{~h}$ in an incubator

${ }^{\mathrm{a}}$ Diameter of inhibition zone $>30 \mathrm{~mm},++++; 21-30 \mathrm{~mm},+++; 16-20 \mathrm{~mm},++; 10-15 \mathrm{~mm},+$; and $<10 \mathrm{~mm},-$ 
Table 5 Minimum inhibition concentrations (MIC) of 4-methoxysalicylaldehyde and its derivatives against foodborne bacteria

\begin{tabular}{|c|c|c|c|c|c|c|}
\hline \multirow[t]{3}{*}{ Compound } & \multicolumn{6}{|l|}{$\operatorname{MIC}(\mu \mathrm{g} / \mathrm{mL})^{\mathrm{a}}$} \\
\hline & \multicolumn{3}{|c|}{ Gram-positive bacteria } & \multicolumn{3}{|c|}{ Gram-negative bacteria } \\
\hline & L. monocytogenes & S. aureus & S. intermedius & S. typhimurium & S. flexneri & S. sonnei \\
\hline 4-Methoxysalicylaldehyde & 41.7 & 51.9 & 67.3 & 30.1 & 59.8 & 40.2 \\
\hline 4-Hydroxysalicylaldehyde & 61.5 & 44.3 & 47.2 & 41.1 & 59.1 & 52.5 \\
\hline Salicylaldehyde & 62.8 & 81.5 & $100<$ & 78.8 & 74.8 & $100<$ \\
\hline 3-Methoxysalicylaldehyde & $100<$ & $100<$ & $100<$ & $100<$ & $100<$ & $100<$ \\
\hline 5-Methxoysalicylaldehyde & 92.1 & 70.0 & 80.7 & 48.5 & 58.2 & 41.3 \\
\hline 3-Methylsalicylaldehyde & $100<$ & $100<$ & $100<$ & $100<$ & $100<$ & $100<$ \\
\hline 5-Methylsalicylaldehyde & $100<$ & $100<$ & $100<$ & $100<$ & $100<$ & $100<$ \\
\hline
\end{tabular}

Cultured on Mueller-Hinton broth at $37{ }^{\circ} \mathrm{C}$ for $24 \mathrm{~h}$ in an incubator

${ }^{\mathrm{a}} \mathrm{MIC}$ values $<100 \mu \mathrm{g} / \mathrm{mL}$

S. intermedius and S. sonnei. However, 3-methoxysalicylaldehyde, 3-methylsalicylaldehyde, and 5-methylsalicylaldehyde did not show inhibitory effects against six foodborne bacteria. Several studies suggested that structural features of a compound determined the differences in their antimicrobial effects [2, 4, 25, 26].

The utilization of natural products may enhance food safety and reduce microbial contamination in many foods. In conclusion, our study showed the possibility of pathogen reduction in foods using natural food preservatives containing 4-methoxysalicylaldehyde and its derivatives. Furthermore, this study elucidated the structural properties of compounds derived from essential oil of $P$. sepium manifesting antibacterial activity.

Acknowledgments This research was supported by Basic Science Research Program through the National Research Foundation of Korea (NRF) funded by the Ministry of Science, ICT and future Planning (2016R1A2A2A05918651).

\section{References}

1. Hussain AI, Anwar F, Sherazi STH, Przybylski R (2008) Chemical composition, antioxidant and antimicrobial activities of basil (Ocimum basilicum) essential oils depends on seasonal variations. Food Chem 108:986-995

2. Gyawali R, Ibrahim SA (2014) Natural products as antimicrobial agents. Food Control 46:412-429

3. Hajji M, Masmoudi O, Souissi N, Triki Y, Kammoun S, Nasri M (2010) Chemical composition, angiotensin I-converting enzyme (ACE) inhibitory, antioxidant and antimicrobial activities of the essential oil from Periploca laevigata root barks. Food Chem 121:724-731

4. Savoia D (2012) Plant-derived antimicrobial compounds: alternatives to antibiotics. Future Microbiol 7:979-990

5. Tepe B, Daferera D, Sokmen A, Sokmen M, Polissiou M (2005) Antimicrobial and antioxidant activities of the essential oil and various extracts of Salvia tomentosa Miller (Lamiaceae). Food Chem 90:333-340
6. Kim HJ, Koo M, Hwang D, Choi JH, Kim SM, Oh SW (2016) Contamination patterns and molecular typing of Bacillus cereus in fresh-cut vegetable salad processing. Appl Biol Chem 59:573-577

7. Bae IK, Kim K, Choi SD, Chang KS, Lee HS, Lee SE (2017) Mosquito larvicidal activities of naturally occurring compounds derived from Piper species. Appl Biol Chem 60:113-117

8. Cowan MM (1999) Plant products as antimicrobial agents. Clin Microbiol Rev 12:564-582

9. Jeon YJ, Lee SG, Lee HS (2017) Acaricidal and insecticidal activities of essential oils of Cinnamomum zeylanicum barks cultivated from France and India against Dermatophagoides spp., Tyrophagus putrescentiae and Ricania sp. Appl Biol Chem 60:259-264

10. Nedorostova L, Kloucek P, Kokoska L, Stolcova M, Pulkrabek J (2009) Antimicrobial properties of selected essential oils in vapour phase against foodborne bacteria. Food Control 20:157-160

11. Itokawa H, Xu J, Takeya K (1988) Studies on chemical constituents of antitumor fraction from Periploca sepium. IV.: structures of new pregnane glycosides, periplocosides D, E, L, and M. Chem Pharm Bull 36:2084-2089

12. Chu SS, Jiang GH, Liu WL, Liu ZL (2012) Insecticidal activity of the root bark essential oil of Periploca sepium Bunge and its main component. Nat Prod Res 26:926-932

13. Zhang MS, Bang IS, Park CB (2012) Lack of mutagenicity potential of Periploca sepium Bge. in bacterial reverse mutation (Ames) test, chromosomal aberration and micronucleus test in mice. Environ Health Toxicol 27:e2012014

14. Kim MG, Lee SE, Yang JY, Lee HS (2014) Antimicrobial potentials of active component isolated from Citrullus colocynthis fruits and structure-activity relationships of its analogues against foodborne bacteria. J Sci Food Agric 94:2529-2533

15. Jeong EY, Jeon JH, Kim HW, Kim MG, Lee HS (2009) Antimicrobial activity of leptospermone and its derivatives against human intestinal bacteria. Food Chem 115:1401-1404

16. Wang J, Liu H, Zhao J, Gao H, Zhou L, Liu Z, Chen Y, Sui P (2010) Antimicrobial and antioxidant activities of the root bark essential oil of Periploca sepium and its main component 2-hydroxy-4-methoxybenzaldehyde. Molecules 15:5807-5817

17. Li Y, Zeng XN, Wang WZ, Luo CH, Yan Q, Tian M (2012) Chemical constituents from the roots of Periploca sepium with insecticidal activity. J Asian Nat Prod Res 14:811-816 
18. Jeong EY, Cho KS, Lee HS (2012) Food protective effects of Periploca sepium oil and its active component against stored food mites. J Food Prot 75:118-122

19. Sreekumar S, Seeni S, Pushpangadan P (2000) Micropropagation of Hemidesmus indicus for cultivation and production of 2-hydroxy 4-methoxybenzaldehyde. Plant Cell Tissue Organ Cult 62:211-218

20. Nagarajan S, Jagan Mohan Rao L, Gurudutt KN (2001) Chemical composition of the volatiles of Decalepis hamiltonii (Wight \& Arn). Flavour Fragr J 16:27-29

21. Verma RS, Mishra P, Kumar A, Chauhan A, Padalia RC, Sundaresan V (2014) Chemical composition of root aroma of Decalepis arayalpathra (J. Joseph and V. Chandras.) Venter, an endemic and endangered ethnomedicinal plant from Western Ghats, India. Nat Prod Res 28:1202-1205
22. Phadke NY, Gholap AS, Ramakrishnan K, Subbulakshmi G (1994) Essential oil of Decalepis hamiltonii as an antimicrobial agent. J Food Sci Technol Mysore 31:472-475

23. Friedman M, Henika PR, Mandrell RE (2003) Antibacterial activities of phenolic benzaldehydes and benzoic acids against Campylobacter jejuni, Escherichia coli, Listeria monocytogenes, and Salmonella enterica. J Food Prot 66:1811-1821

24. Stojković D, Petrović J, Soković M, Glamočlija J, Kukić-Marković J, Petrović S (2013) In situ antioxidant and antimicrobial activities of naturally occurring caffeic acid, p-coumaric acid and rutin, using food systems. J Sci Food Agric 93:3205-3208

25. Iwasa K, Nanba H, Lee DU, Kang SL (1998) Structure-activity relationships of protoberberines having antimicrobial activity. Planta Med 64:748-751

26. Pelttari E, Karhumäki E, Langshaw J, Peräkylä H, Elo H (2007) Antimicrobial properties of substituted salicylaldehydes and related compounds. Z Neuropsychol 62:487-497 